\title{
Jericho-off-the-Record: Tracing 'New' Records of the 1950s Excavations at Tell es-Sultan
}

\author{
Archaeology
}

\author{
Bart Wagemakers \\ University of Applied Sciences Utrecht \\ bart.wagemakers@npaph.com
}

\begin{abstract}
During the last few years the Non-Professional Archaeological Photographs project (NPAPH) has gathered and digitised numerous forgotten non-professional photographs and slides from past archaeological excavations (1950-1980), which were subsequently ingested and processed at DANS. The term 'non-professional' refers to participants of excavations who were not part of the trained staff but who supported the dig as part of their continuous education or out of interest. Secondly, this category of documentation also includes private photographs, slides and films made at the excavation by the archaeological staff and which are not stored in official archives. Several NPAPH publications have previously demonstrated that this category of records is of significance to current archaeological research. The NPAPH has recently initiated a new project: Jericho-off-the-Record. This project aims to gather not only visual nonprofessional documentation of the second British campaign to Tell es-Sultan (ancient Jericho) but also to collect written and oral records of the renowned excavation, which was conducted by Kathleen Kenyon from $195^{2}$ till 1958 . This article provides an update of the situation regarding the current project of which an initial data deposit has been made accessible in EASY, the DANS online archiving system.
\end{abstract}

\section{Keywords}

Jericho - Tell es-Sultan - NPAPH - Kathleen Kenyon - non-professional - archive

- See the showcase of the data in the Exhibit of Datasets: http://dansdatajournal.nl/rdp/dsdoc.html?id=wagemakers2016

(C) BART WAGEMAKERS, 2016 | DOI:10.1163/24523666-01000005

This is an open access article distributed under the terms of the prevailing CС-BY license at the time of publication. 


\section{Introduction}

I was woken by a blinding light - it was the sun! Through the window I could see palm trees, flowers and birds all against a brilliant blue sky. Coming from the drab greyness of post-war England, I felt as if the lights had turned on for the first time in my life.

CARSWELL, 2014

This is how John Carswell, an artist in his early twenties, who had just graduated from the Royal College of Art in London and suddenly become a draughtsman at the archaeological expedition to Jericho, recalled his first impression of the site where he was to work for several months in 1954-1955.

Tell es-Sultan, ancient Jericho, is an iconic site with a long and impressive history stretching from the prehistory to the present day. Once dubbed the 'oldest city in the world' (Figure 1), it has been the focus of intense archaeological activity and media interest during the 150 years since its discovery. Considering the 1950s, a period when the second British campaign, conducted by Kathleen Kenyon, drew attention to the site because of its rigorous application of archaeological method, through to the more recent Italian-Palestinian Expedition, Tell es-Sultan and its surrounding landscape has always played a key role in our understanding of this region (Figure 2).

In recent years the Non-Professional Archaeological Photographs project (NPAPH) has already demonstrated that documentation made by so-called 'non-professionals' is of great significance to current archaeological research (Wagemakers, 2015; idem, 2014; Wagemakers \& Ameling, 2012; Wagemakers \& Taylor, 2011). The term 'non-professional' refers to participants of excavations who are not part of the trained staff but who support the dig as part of their continual education or out of interest, such as students, volunteers, reporters and sponsors. Secondly, this category of documentation includes the private photographs, slides or films made at the excavation by the archaeological staff and which are not stored in official archives.

As a result of conversations I have had with non-professionals who participated in the 1952-1958 expedition to Tell es-Sultan - such as the artist John Carswell - it became clear to me that, although the results of the campaign were published in numerous articles and reports (e.g. Kenyon, 1960-1983; idem, 1957; idem, 1956), a considerable number of noteworthy non-professional records from that excavation had fallen into oblivion. Thanks to the project 'Jericho-off-the-Record', recently initiated by $\mathrm{NPAPH}$, these records are now being traced, collected, digitised, ingested and processed at DANS, and made accessible to the public via digital archives. 


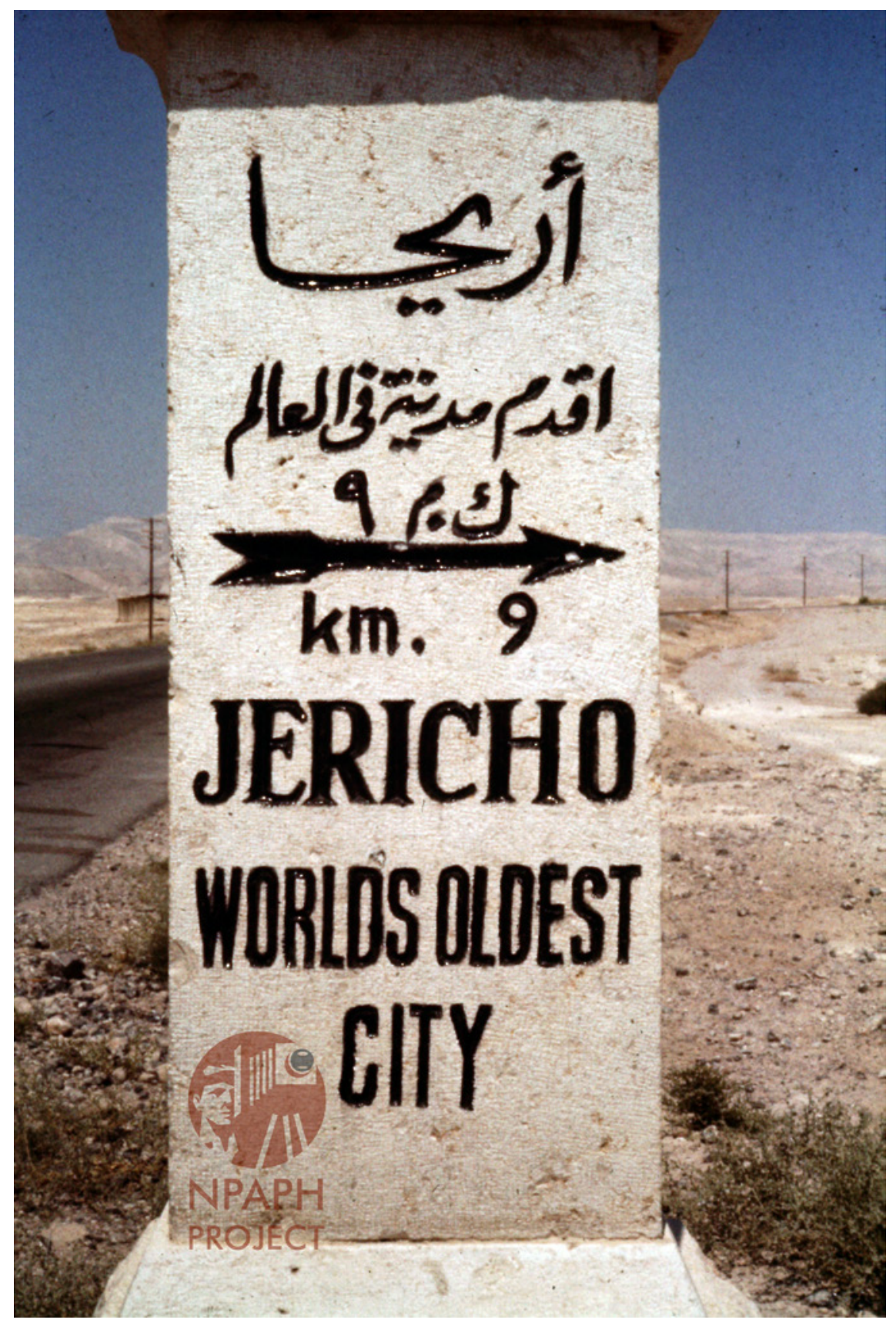

FIGURE 1 Jericho, 'oldest city in the world'?

PHOTOGRAPH: A. DOUGLAS TUSHINGHAM 


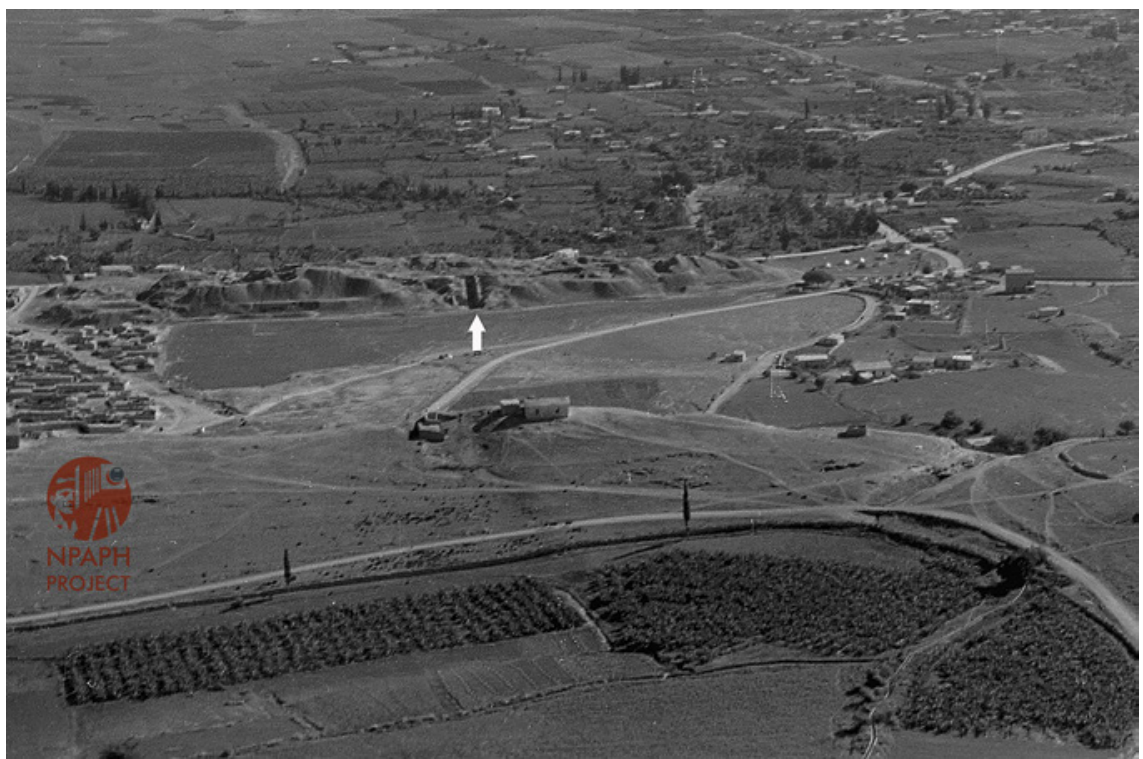

FIGURE 2 General view of Tell es-Sultan in 1954. Note the deep cut of Kenyon's Trench I across the western side of the mound (marked by the white arrow), and the refugee camp located next to the northern side. The white tents of the digging camp are set up on the southern side.

PHOTOGRAPH: LEO BOER

\section{Problem}

Unfortunately, the 'non-professional' documentation, including photographs, slides, field notes, letters, drawings, and - last but not least - the former participants' memories, had generally been neglected in the past. Unlike official records, that can be consulted in published reports and are stored in libraries, museums, archives and on the internet, documentation by non-professionals is generally not accessible to the public. Due to the fact that this category of documentation is usually kept in private homes, it is frequently stored in unfavourable conditions, which can often result in damage to the documents. In the case of black-and-white photographs, for example, irreversible damage depending on the conditions of the storage space - generally occurs within 70 years after the photographs have been taken. Impairments such as de-silvering, yellowing, acidity and broken glass negatives are common. Deterioration of colour photographs - showing visible changes resulting from colour fading is even more rapid (Gschwind et al., 2005, 123-124). The fact that they have been stored in private houses, rather than in official archives, makes that they are slowly forgotten over the course of time. 
This neglect is undeserved, because this type of documentation remains significant to current archaeological research in several ways. In contrast to the official expedition documentation, in the case of Jericho ordered and arranged by Kathleen Kenyon and several specialists, the non-official records were initiated by the expedition members themselves and therefore show those aspects of the dig that fascinated them personally. Since this type of documentation is not the result of the official recording policy of the expedition, it also contains excavation features that differ strongly from those that are usually discussed in annual reports or final publications (Figure 3).

The gathering, digitising and making accessible of the 'non-official' documentation of excavations in the past is significant to current archaeological research in several ways:

A - The 'new' records may well serve to supplement the existing documentation of the excavation. As the new material may provide (different) images and perspectives of excavation features that were not present in the official

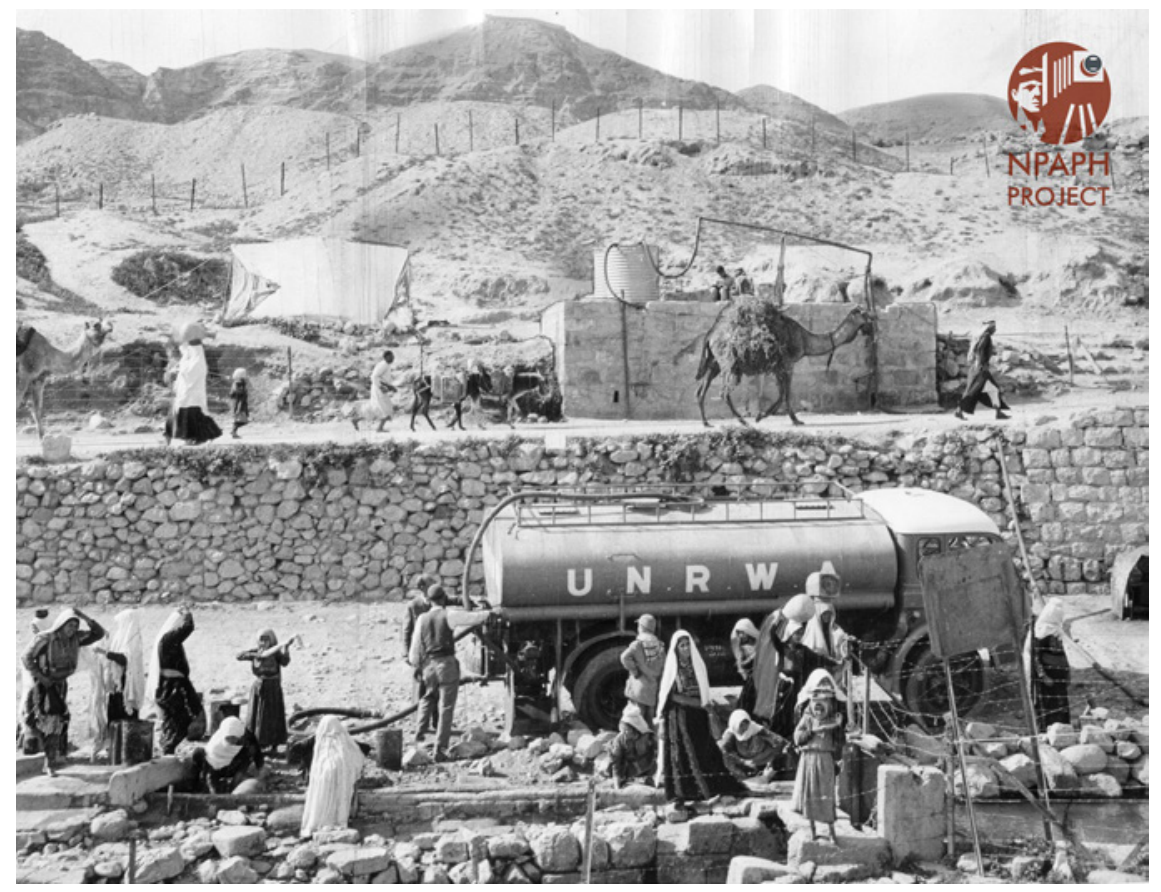

FIGURE 3 David Spurgeon of the Toronto Globe and Mail reported the 1956 season 'directly' from the tell. He was not only interested in archaeological features, but also in the (political) circumstances of the region. This picture shows the United Nations Relief and Works Administration truck and women from the refugee camp, which was located adjacent to the northern side of the tell. PHOTOGRAPH: DAVID SPURGEON 


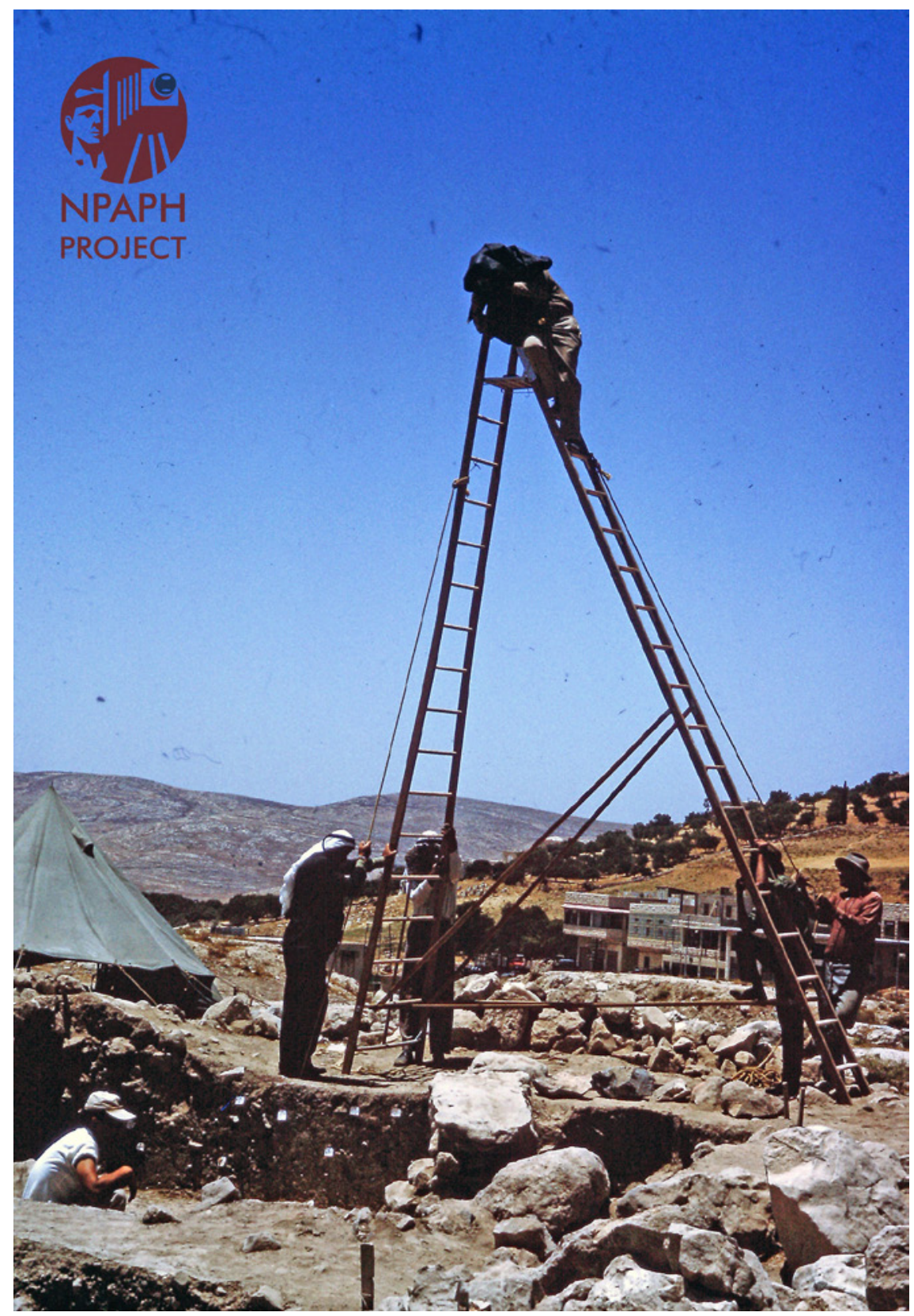

FIGURE 4 The way features at Tell Balata were recorded from above in the 1960 . PHOTOGRAPH: DAN T. HUGHS 
documentation, this set of data can serve as additional scientific information to any current archaeological research. The developments in archaeological recording seem to suggest that there might be a difference between what we today expect staff members to document, and what they actually recorded at that time (Wagemakers, 2014). The type of documentation we now want to add to the NPAPH-site, may be able to fill some gaps in the official documentation as they might show some features or details of the site that have not (sufficiently enough) been recorded by professional photographs and draughtsmen.

B - The aspect of the 'history of archaeology'; it gives an insight into the circumstances of past excavations, the people who joined the dig, the techniques and methods used at the time (Figure 4), the way the campaign was organised and the relations between archaeological institutions in the region (Wagemakers, 2015). Furthermore, it provides an impression of the personal experiences of the former participants. Their narratives reveal the smaller, more personal stories of the excavation. All this information is important for creating a more complete picture of the expeditions and their historical context.

$\mathrm{C}$ - By comparing 'non-official' records with the official ones, it is also possible to get an impression of the official documentation policy of archaeological campaigns carried out in the past. 'Non-official' records of particular features or phases of the excavation, which are not available in the official documentation, reveal the decisions the staff has taken at the time on what to record and what to ignore. The ability to compare the two categories of documentation offers insights into the development of the documentation methodology within the archaeological discipline.

D - It is important to store this newly-discovered documentation in a digital form and make it accessible to both scholars and the general public through an open platform. Using digitised material prevents any potential damage to the original and makes it possible to make endless copies of the material without any loss of quality (Gschwind et al., 2005, 123).

\section{Methods}

The project Jericho-off-the-Record gathers three types of data: visual, written and oral records. The first section concerns photographs, slides, drawings and footage. Private notes, letters and diaries represent the written section. Finally, personal stories and memories of former participants of their stay at the excavation form the oral history section. However, in order to be able to obtain those valuable records, we first need to locate those former participants first. 
Generally, the first step is to find the names of the people concerned. This information can often be found in the acknowledgements section or the staff lists published in annual reports or concluding publications. Secondly, on the basis of the collected names we then search for contact details of the non-professionals. Initially, we search the internet, using search engines and network media such as LinkedIn and Academia.edu. If this search is not successful, we then contact (former) employers or other archaeological institutions, who generally have access to the required contact details held in their administration or via their relations with university alumni and student clubs. The former field director of the excavation concerned can sometimes also provide telephone numbers, email or postal addresses. Finally, another successful alternative approach is by word of mouth. The archaeological world can often seem very small. When no contact details of the former participants have been found by using our active approach, we then apply the passive approach, which means placing an appeal for information using the social media, including our website, Facebook page and Twitter account or other archaeological internet media.

Having gathered some contact details, we then get in touch with the people concerned and ask them the crucial question: do they have any documentation of the excavation in their possession? And are they able and willing to record their recollections of their experiences at the site? If they do, an inventory is then made of the collection and the possibilities of digitising the material are investigated.

Once the collection has been digitised, the descriptive metadata fields are filled out as completely as possible. This information is crucial as it provides the context of the resources without which the photographs or films are useless. In short, only in combination with these metadata can non-professional material be of any value to the existing professional archaeological documentation.

The metadata include a unique code, name, type of source, repositories, name of creator, dates, archaeological sites and caption. In addition, the archive contains an introduction, which clarifies the origin of the collection, gives information about the creators of the material and provides other essential details.

As the principle aims of this project are to study and preserve forgotten archaeological data for the future and to make them accessible to the public, a national data repository and a website are used to achieve these goals. All material from the visual, written and oral sections, traced and digitised within the Jericho-off-the-Record project, is then archived with DANS in order to preserve the data for future use. Furthermore, in order to disseminate the outcomes of the project, the digital archive is going to be made accessible via the 
NPAP H-website in autumn 2016, which enables users to search through the records that have been traced and digitised by the project.

\section{Data}

Since Jericho-off-the-Record is still a project in progress and we are about to analyse and study the records gathered so far, the data set is as yet partially accessible. In order to get an idea of the nature of the new Jericho archive, an initial data deposit has been made in EASY, the DANS online archiving system. This initial data deposit holds 33 colour slides belonging to A. D. Tushingham, the Assistant Director of the Jericho excavations in the 1950s.

So far, Jericho-off-the-Record has resulted in an imposing and diverse collection of records. The complete data-set includes 565 black-and-white photographs, 52 colour slides (among them 11 glass negatives), 63 letters, one diary which describes the progress on the site in detail, and even one $16 \mathrm{~mm}$-colour film. This footage is unique, since the only film recording generally known to exist, is the black-and-white ввс documentary "Buried Treasure: The Walls of Jericho", recorded in 1956. While this ввс documentary - hosted by the renowned archaeologist Mortimer Wheeler, Kathleen Kenyon's mentor shows a fixed set-up of excavation phases, the newly discovered footage gives insight into camp life and the progression of the dig from the point of view of a non-professional. Furthermore, we conducted nine interviews with former participants (Figure 5). In order to create a balanced view, we successfully searched for British, American and Canadian as well as Palestinian oral records.

This archaeological documentation, after having fallen into oblivion for six decades is now rediscovered and brought together by the Jericho-off-theRecord project. It will provide both researchers and the general public an interesting picture of the historical context of the excavation and the circumstances during the archaeological campaign shortly after the end of World War II and the founding of the State of Israel.

The project also contains a Dutch feature in the person of Henk Franken. After working as a missionary in Bali, he returned to the Netherlands in $195^{1}$ and wrote a dissertation. He was subsequently appointed to the Faculty of Theology at Leiden University as a lecturer in Palestinian Antiquities. That position required archaeological skills which he obtained by joining Kenyon's excavations in Jericho from 1955 until 1958 (Figure 6). Only two years after the Jericho expedition was ended, Franken embarked on the first Dutch excavation in The Hashemite Kingdom of Jordan, at Tell Deir Allā. He used the knowledge 


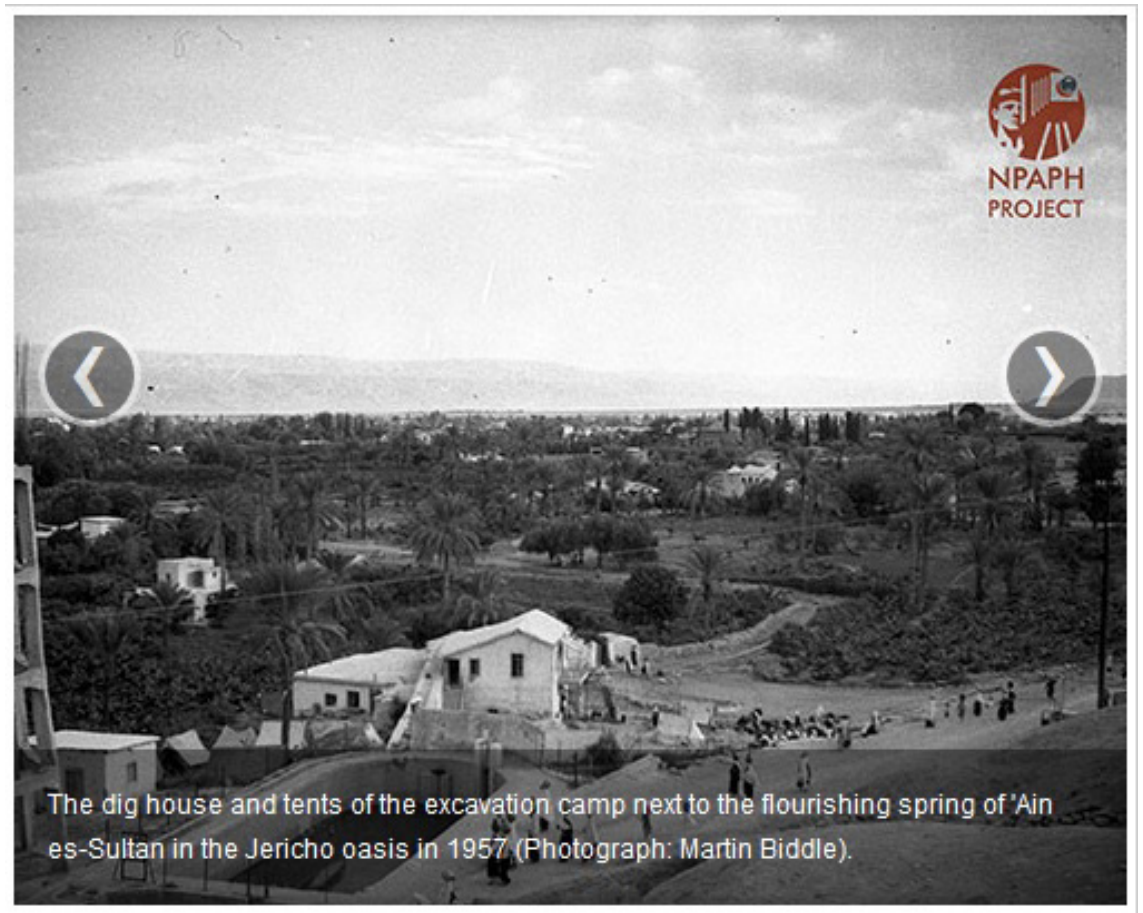

FIGURE 5 Jericho-off-the-Record image carrousel. (View here: http://dansdatajournal.nl/rdp/ dsdoc.html?id=wagemakers2016).

and experience from the Jericho excavations both in his teachings at Leiden University and at his expedition to Tell Deir Allā, where numerous students gained experience in fieldwork and became acquainted with his archaeological views. From this point of view, the impact of the Jericho campaign on Dutch archaeology in the Near East should not be ignored (Wagemakers, forthcoming). Therefore, we are pleased to be able to include Franken's diary and field notes in the Jericho-off-the-Record archive.

\section{Concluding Remarks}

At the moment of this article's submission the gathered data are being studied and the outcomes of the research will be published in the near future. In this study the non-professional material is compared to the 'official' records published by the staff, so as to determine in what ways they differ from each other. 


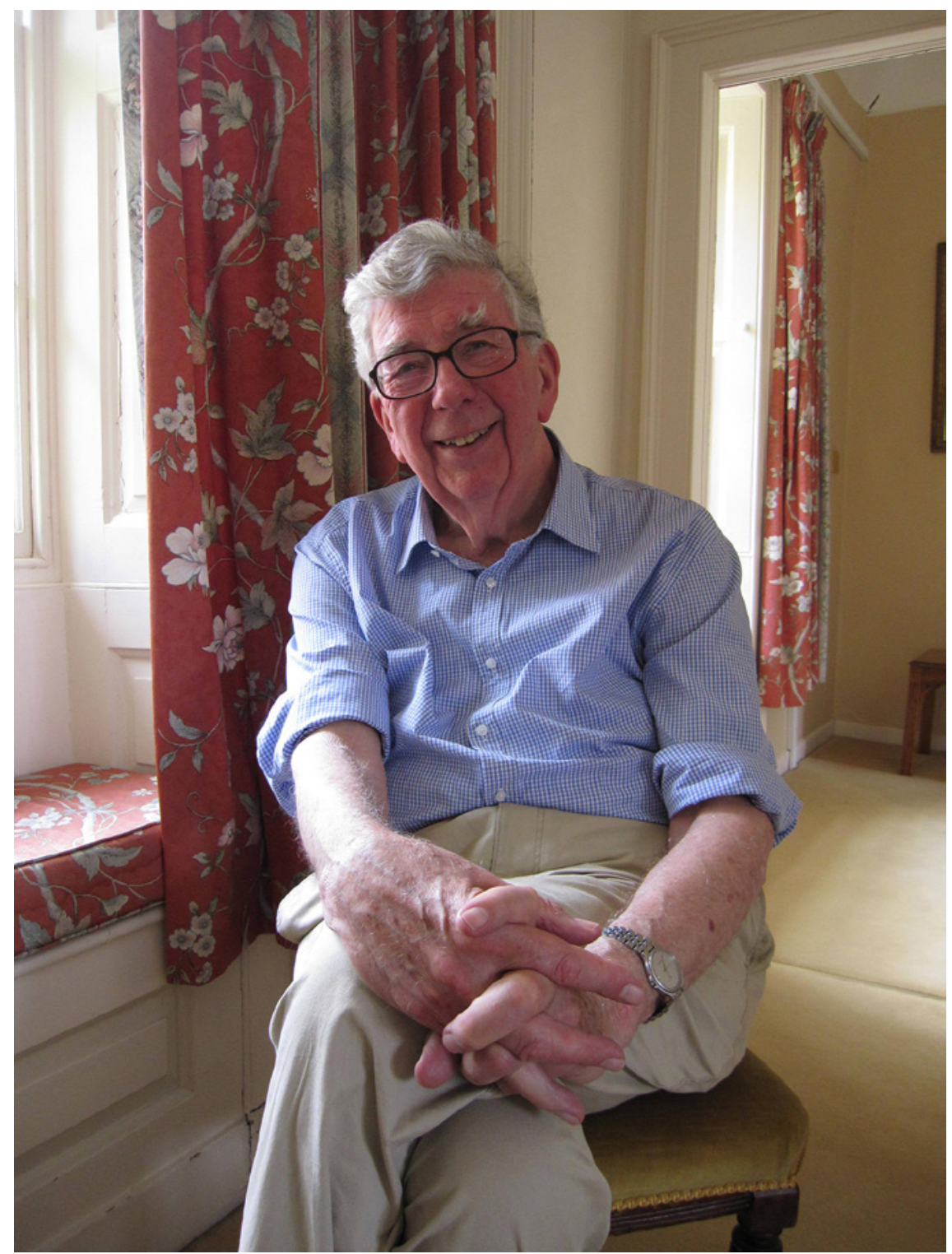

FIGURE 6 One of the interviewed former participants is Martin Biddle, who was sent to Jericho in 1957 in order to fulfill the last four months of his National Service by excavating at Tell es-Sultan.

PHOTOGRAPH: BART WAGEMAKERS 


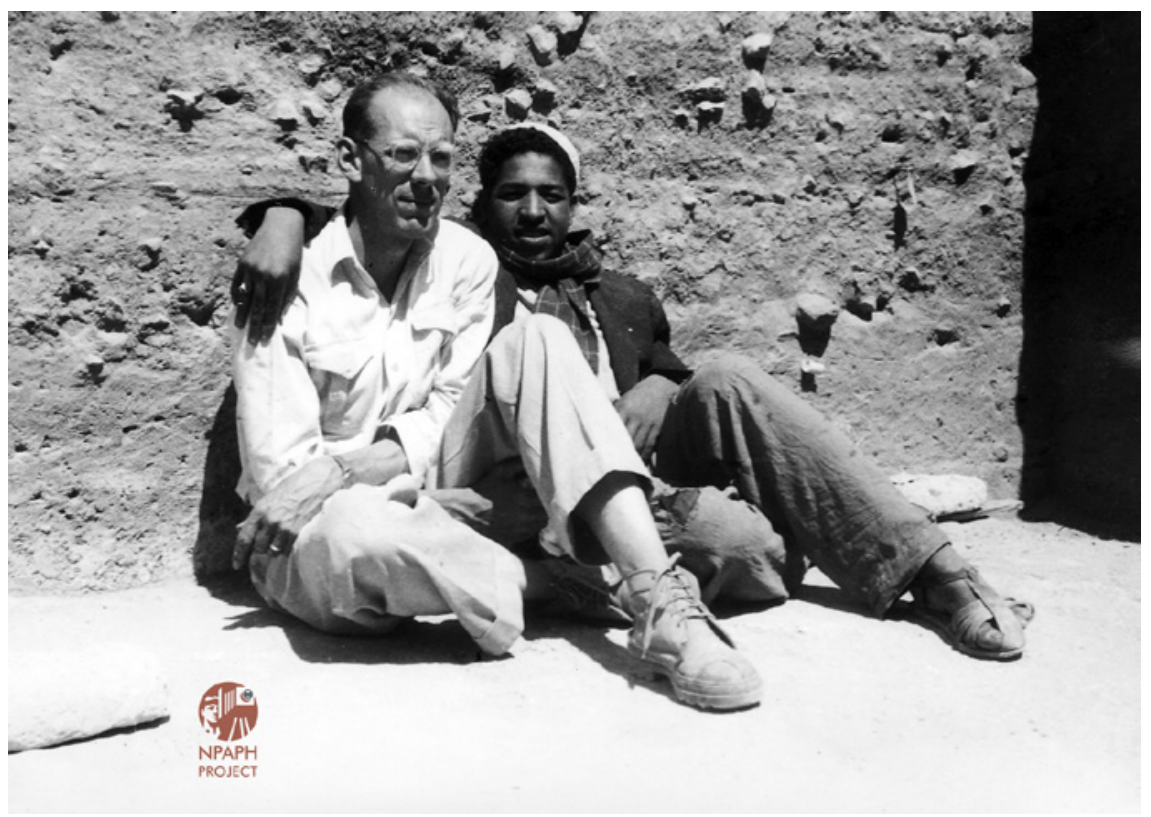

FIGURE 7 Henk Franken and a local labourer at Tell es-Sultan.

COURTESY DUTCH NATIONAL MUSEUM OF ANTIQUiTIES

Although the data are still in the process of being studied, Jericho-off-theRecord has already demonstrated that non-professional records - created sixty years ago - can still be traced today. Due to the often abominable conditions of the material storage space of the non-professionals and the average advanced age of this target group, it is important that efforts are made now to secure this valuable category of documentation. Thanks to the numerous photographs, slides, letters, interviews and even a film secured by the project, we are able to create a more complete picture of the expedition and its historical context. The records give a clear insight into the way former participants experienced daily life at the excavation, show what the informal relationships between the participants were like, and show the extent in which the dig was influenced by the political circumstances of the time. By all of this, Jericho-off-the-Record gives a face to the people who long ago uncovered the fascinating history of ancient Jericho.

\section{Acknowledgements}

I wish to thank the following people for providing me with unpublished archaeological documentation and for their implicit support for this research: 
Martin Biddle, Annemie Boer, John Carswell, Dan T. Hughs, David Spurgeon, Maggie and Margot Tushingham.

\section{References}

Carswell, J. (2014). In Honour of Honor: the Birth of Underwater Archaeology. The Honor Frost Foundation Lecture, June 11 2014. The British Academy, London.

Gschwind, R., Rosenthaler, L., Schnider, R., Frey, F. \& Frey, J. (2005). Digital image picture archives. Theory and practice in Switzerland. In Hemsley, J., Cappellini, V. and Stanke, G. (Eds.), Digital Applications for Cultural and Heritage Institutions (pp. 123132). Aldershot: Ashgate Publishing Limited.

Kenyon, K. M. (1960-1983). Excavations at Jericho, Vols. I-V. London: The British School of Archaeology in Jerusalem.

Kenyon, K. M. (1957). Digging UpJericho. London: Ernest Benn Limited.

Kenyon, K. M. (1956). Jericho and its Setting in Near Eastern History. Antiquity: A Quarterly Review of Archaeology, 30, 184-195.

Wagemakers, B. (forthcoming). The Impact of Kenyon's Excavations at Tell es-Sultan on Dutch Archaeology in the Near East. In B. Finlayson, R. Sparks, \& B. Wagemakers (Eds.). Digging up Jericho: Past, Present \& Future. Levant Supplementary Series. London: Council for British Research in the Levant.

Wagemakers, B. (2015). Fallen into Oblivion: the 1956 Greek-Dutch Expedition to Archanes on Crete. Bulletin of the History of Archaeology, 25(1), Art 1. doi: http://doi. org/10.5334/bha.251.

Wagemakers, B. (2014). The Digital Non-Professional Archaeological Photographs Archives: Private Photographs of Past Excavations for Current Archaeological Research. Archaeological Review from Cambridge, 29.2, 50-68.

Wagemakers, B. \& Ameling, W. (2012). A new photograph and reconsidered reading of the lost inscription from Khirbet el-Khalidi (IGLSyr 21, 4 137). Zeitschrift für Papyrologie und Epigraphik, 183, 176-178.

Wagemakers, B. \& Taylor, J.E. (2011). New photographs of the Qumran excavations from 1954 and interpretations of L.77 and L.86. Palestine Exploration Quarterly, 143(2), 134-156. 